\title{
A strukturális és a szintaktikailag jelöletlen fókusz interpretációjának összehasonlító elemzése
}

\author{
Tóth Enikö \\ DE Angol-Amerikai Intézet \\ Csatár Péter \\ DE Germanisztika Intézet
}

\begin{abstract}
Összefoglaló
Tanulmányunkban egy percepciós kísérlet eredményét mutatjuk be, amely során a strukturális, illetve a szintaktikailag jelöletlen fókusz (tág VP fókusz) értelmezését vizsgáltuk ugyanabban a dizájnban a magyar nyelvben. A résztvevők egy kép-mondat megfeleltetési feladat során, hatfokú Likert-skálán ítélték meg egy kép és egy kiegészítendő kérdésre adott válaszként megjelenő tesztmondat összeillőségét. Eredményeink nem mutattak szignifikáns különbséget a strukturális és a szintaktikailag jelöletlen fókusz interpretációja között a két tesztelt faktor, a kimerítőség és a vártság szempontjából. Egyfelöl, a kísérletben mindkét fókuszstruktúra esetében a kimerítő olvasat bizonyult preferáltnak. Másfelől, a fókuszkonstituens várt, vagyis adott szituációban a világtudásunkhoz képest előrejelezhető volta egyik vizsgált struktúra esetében sem bizonyult döntőnek. Összességében eredményeink empirikusan alátámasztják Surányi (2011) elméleti felvetését a szóban forgó fókuszstruktúrák értelmezéséről.
\end{abstract}

Kulcsszavak: fókusz, kimerítőség, vártság, kísérletes pragmatika

\section{Bevezetés}

A magyar generatív nyelvészeti kutatás hagyományosan a fókusz két típusát különbözteti meg: az ún. strukturális vagy más néven preverbális fókuszt, valamint a szintaktikailag jelöletlen vagy információs fókuszt (É. Kiss 1998). A strukturális fókuszt a nyelvhasználatban prominens hangsúly jelöli, a fókuszált összetevő az ige előtti pozícióba mozog, és abban az esetben, ha a mondatban igekötő is van, az igekötő posztverbális helyzetben jelenik meg:

(1) Mari egy kalapot nézett ki magának.

(É. Kiss 1998: 249)

A szintaktikailag jelöletlen fókusz esetében a fókuszált elem alaphelyzetben marad, nem mozgatjuk:

(2) Mari kinézett magának egy kalapot.

(É. Kiss 1998: 249) 
A hagyományos megközelítés a strukturális fókuszhoz kimerítő olvasatot rendelt; a kimerítőséget pedig inherens szemantikai tulajdonságként kezelte, vagyis az értelmezendő mondat igazságfeltételei részének tekintette (É. Kiss 1998; Kenesei 1986; Szabolcsi 1981; 1994). Az elmúlt időszakban azonban empirikus kutatásokra támaszkodva többen is megkérdőjelezték ezt a felfogást. Wedgwood (2005) relevanciaelméleti keretben korpuszból nyert adatok alapján amellett érvelt, hogy a kimerítő értelmezés egy pragmatikai implikatúra eredménye. Később kísérletes tanulmányok is kritikával illették a hagyományos felfogás azon elemét, amely szerint a kimerítőség a strukturális fókusz inherens szemantikai tulajdonsága (vö. Onea-Beaver 2011; Kas-Lukács 2013), és amellett foglaltak állást, hogy a strukturális fókusz kimerítősége pragmatikai eredtű jelenségként írandó le.

A szintaktikailag jelöletlen fókusz funkciója É. Kiss (1998) megközelítésében az, hogy a diskurzusban új, nem előfeltételezett információt jelöl. Továbbá arra is felhívja a figyelmet, hogy „ha a válasz [egy kiegészítendő kérdésre] kimerítő, [...] akkor strukturális fókuszként kell megjelennie"1 (É. Kiss 1998: 250). Ez pedig azt implikálja, hogy a szintaktikailag jelöletlen fókusz nem fejezhet ki kimerítő azonosítást.

Ezzel szemben Surányi (2011) felvetette annak a lehetőségét, hogy bizonyos kontextusokban a szintaktikailag jelöletlen fókusz is értelmezhető kimerítő módon. ${ }^{2}$ További empirikus vizsgálódások szükségességére is felhívta a figyelmet, mivel felvetése a saját intuícióján, illetve csak kisszámú anyanyelvi beszélőtől származó, nem szisztematikusan összegyüjtött adaton alapult. Jelen írásunkban Surányi (2011) felvetését alapul véve egy percepciós kísérletet mutatunk be, amelyben a következőkre vállalkoztunk:

(i) olyan empirikus adatok gyüjtésére, amelyek igazolhatják vagy cáfolhatják Surányi (2011) hipotézisét a szintaktikailag jelöletlen fókusz kimerítő olvasatának lehetőségéről;

(ii) további adatok gyűjtésére a strukturális fókusz kimerítő olvasatának jellemzéséhez;

(iii) a két vizsgált fókusztípus interpretációjának összevetésére ugyanabban az empirikus keretben, mégpedig annak érdekében, hogy minél pontosabb képet kapjunk arról, hogy az anyanyelvi beszélők miként értelmezik a szóban forgó fókuszstruktúrákat.

\section{Háttér}

\subsection{Korábbi kísérletes munkák a strukturális fókuszról}

Az egyik legfontosabb elméleti probléma a strukturális fókusz értelmezéséhez kapcsolódóan az, hogy milyen módon magyarázzuk a kimerítő olvasat jelenlétét. Mint azt korábban már jeleztük, több kísérletes munka érvel amellett, hogy a kimerítőség nem tartozik a strukturális fókusz inherens szemantikai tulajdonságai

1 „, if the answer [to a wh-question] is exhaustive, [...] it must be put as a preverbal identification focus" (É. Kiss 1998: 250).

${ }^{2}$ Jelen tanulmány szempontjából jelentősége van a szűk fókusz vs. tág fókusz megkülönböztetésének a szintaktikailag jelöletlen fókusz esetén. Erröl bővebben I. Surányi (2011) és itt a 2.2. részt. 
közé, hanem pragmatikai implikatúraként aktiválódik (vö. pl. Onea-Beaver 2011; Kas-Lukács 2013). ${ }^{3}$

Az újabb kísérleti eredmények szintén a strukturális fókusz kimerítőségének pragmatikai értelmezését támogatják. Babarczy-Balázs (2016) relevanciaelméleti keretben érvelnek amellett, hogy a strukturális - az ő terminológiájukban: preverbális - fókusz kimerítősége pragmatikai levezetés révén áll elő, közelebbről skaláris implikatúra eredménye. Ez azt jelenti, hogy nem kimerítő kontextusban a strukturális fókusz információtartalma alulspecifikált, így mentális feldolgozásához nagyobb kognitív erőfeszítés szükséges. Babarczy-Balázs (2016) kísérletében óvodáskorú gyermekek, kisiskolások és felnőtt anyanyelvi beszélők kép-mondat párok összeillőségét ítélték meg egy háromfokozatú skálán. Minden tesztmondat strukturális fókuszt tartalmazott, a képek pedig kimerítő, nem kimerítő és referenciálisan hamis kontextust ábrázoltak. Az óvodáskorú gyermekekről azt feltételezték a szerzők, hogy nem kimerítő kontextus esetén nem egyértelmü válaszokat adnak majd a háromosztatú skálán, míg a kisiskolások és a felnőttek, tekintve, hogy már teljesen kifejlődött a pragmatikai jelentések iránti érzékenységük, egyöntetűbben a skála középső értékét részesítik majd előnyben (azaz sem az igaz, sem a hamis érték felé nem mozdulnak el az eredmények, hanem a se-nem-igaz, se-nem-hamis válasz lesz domináns). A kísérlet során a kognitív érettség és az információtartalom tekintetében alulspecifikált szerkezetek (strukturális fókusz) értelmezésének képessége közötti összefüggést is igyekeztek feltárni, és megmutatták, hogy a kettő között korreláció van: a kognitív képességeik érettsége terén előbbre járó gyermekek a felnőttekhez hasonló viselkedést mutattak az értékelési feladat során. ${ }^{4}$ Összességében tehát Babarczy-Balázs (2016) eredményei a strukturális fókusz kimerítőségének pragmatikai megközelítését támogatják.

Pintér (2016) szintén egy mondat-kép megfeleltetési feladat segítségével vizsgálta a strukturális fókusz kimerítőségét négy korcsoportban (6, 7 és 9 éves gyermekek körében, valamint egy felnőtt kontroll csoportban). Kísérletében arra is rámutatott, hogy a bináris megítélési forma nem alkalmas a strukturális fókuszra vonatkozó nyelvi intuíciók tesztelésére. Ez utóbbi feltevésnek az igazolására Pintér két különböző kísérleti dizájnt alkalmazott. Az első kísérletben a résztvevők arról döntöttek, hogy egy strukturális fókuszt tartalmazó mondat illeszkedik-e egy képhez (igaz vagy hamis). Ezzel szemben a második kísérletben a részvevők egy háromosztatú skáláról választottak (vö. Babarczy-Balázs 2016). Pintér eredményei megerősítették az elvárásait: a különböző korcsoportok közötti eltérések felderítésére és rögzítésére a bináris értékelési mód nem bizonyult megfelelőnek, a háromosztatú skálával ugyanakkor megragadhatók voltak a korcsoportok közötti szubtilis eltérések is. A 7 éves vagy annál idősebb gyermekek a felnőttekéhez hasonló viselkedést mutattak a háromosztatú skála alapján, míg a kisebb, óvodáskorú gyermekek nem voltak érzékenyek a strukturális fókusz kimerítőségére. Mindemellett a reakcióidő elemzése azt mutatta, hogy a felnőtt résztvevőknek nem volt szükségük több időre ahhoz, hogy visszautasítsanak egy mondatot egy nem kimerítő kontextusban, mint ahhoz, hogy elfogadják ugyanazt a mondatot az igaz kontrollkondíció

\footnotetext{
${ }^{3}$ Ezen kísérletek részletes ismertetését l. Gerőcs-Babarczy-Surányi (2014) cikkében.

${ }^{4} A$ résztvevők kognitív képességeinek felméréséhez független sztenderd teszteket használtak, pl. N-back tesztet és Dimensional Card Sorting feladatot (Babarczy-Balázs 2016: 156-157).
} 
esetén. Pintér (2016) szerint ezek az eredmények arra utalnak, hogy a strukturális fókusz kimerítősége előfeltevésként, és nem inherens szemantikai tulajdonságként vagy implikatúraként írható le.

Skopeteas-Fanselow (2011) két kísérletet végzett négy nyelv (német, spanyol, görög és magyar) bevonásával, és azt vizsgálta, hogy a fókuszba helyezés müveletét vajon befolyásolják-e különféle diskurzushoz kapcsolódó tényezők. Először arra a kérdésre keresték a választ, hogy a kimerítő értelmezés vajon kötelező-e vagy sem. Ha ugyanis nem kötelező, úgy a megjelenése a diskurzust meghatározó tényezők függvénye. A résztvevők az első kísérletben egy kérdőívet töltöttek ki, amelyben a tesztelemek egy kiegészítendő kérdésből és egy arra adott válaszból álltak:

Kérdés: Mit fogott Matyi?

Válasz: Pisztrángot fogott Matyi. (Skopeteas-Fanselow 2011: 1694-1695)

A válaszban a tárgyi konstituens többek között strukturális fókuszban jelent meg. A kérdés-válasz pár elolvasása után a résztvevőknek igaz vagy hamis válasszal azt kellett megítélniük, hogy milyen mértékben volt kimerítő a válasz egy olyan kérdésre, hogy Lehetséges, hogy Matyi más halakat is fogott? (Skopeteas-Fanselow 2011: 1695). Ezután még egy hétfokozatú Likert-skálán is finomították válaszukat (7: további alternatívák lehetségesek, 1: további alternatívák ki vannak zárva). Skopeteas-Fanselow (2011) eredményei azt mutatták, hogy a vizsgált nyelvek közül a magyar viselkedése eltér a többi nyelvétől, mivel megfigyelésük szerint a magyarban a strukturális fókusz kimerítő értelmezése kötelező.

Ugyanakkor itt rá kell mutatnunk arra, hogy a tesztelt magyar példamondatok túlságosan jelöltek ${ }^{5}$ - legalábbis a jelen tanulmány szerzőinek anyanyelvi intuíciója alapján. (Vö. Pintér (2016) hasonló irányú megjegyzéseit Skopeteas-Fanselow 2011 magyar nyelvi adatairól.) Skopeteas-Fanselow (2011) első kísérletével kapcsolatban felmerül továbbá az a módszertani probléma is, hogy a résztvevőknek egy eldöntendő kérdésre adott válaszként kellett skaláris ítéletet alkotniuk.

Második kísérletében Skopeteas-Fanselow (2011) Zimmermann (2008)-nak a jelölt szerkezetek használatára vonatkozó általános, nyelvközi felvetését vizsgálta ugyanabban a négy nyelvben. Zimmermann (2008) amellett érvel, hogy a beszélők azért döntenek egy - szintaktikailag és/vagy prozódiailag - jelölt konstrukció használata mellett, mert a hallgató számára jelezni szeretnék, hogy a jelölt szerkezetben közölt információ a világról való ismereteinkhez ${ }^{6}$ képest meglepő, nem várt, nem

\footnotetext{
${ }^{5}$ Például (3) esetén, amikor csak egy puszta névszó áll fókuszban, a válasz lehetséges értelmezése az, hogy Matyi pisztrángot fogott, és nem márnát, sügért, süllöt, stb. Tehát, a halak különböző fajtáit vetjük össze egymással, nem pedig a Matyi által kifogott halakat, amire a teszt irányul, ahogyan azt a többi nyelvből közölt tesztelemek, így a következő német nyelvű példa is, visszaigazolják: Eine Forelle hat Matthias geangelt. (Skopeteas-Fanselow 2011: 1965).

${ }^{6}$ Destruel-Velleman (2014) Zimmermann (2008) feltevését az angol szétszakított szerkezetekre tesztelte, azt vizsgálva, hogy az valóban az elvárásainkkal szembeni konfliktus kifejezőeszközének tekinthető-e. Kétféle elvárást különböztettek meg, a világtudásunkon alapuló, illetve az adott diskurzushoz kapcsolódó elvárásokat. Ezek közül a jelen tanulmányban a világtudásunkon alapuló elvárások fontosak, ezt Destruel-Velleman (im. 199) így határozza meg: „a világról alkotott hiedelmek, amelyek állításként vagy előfeltevésként kerülnek kifejezésre" („,beliefs about the world, expressed as assertions or presuppositions”).
} 
előrejelezhető az adott szituációban. Zimmermann (2008) ezt a feltevését több nyelvre is kiterjeszti, azonban megjegyzi, hogy a magyar strukturális fókusz mint jelölt struktúra kivételt képezhet az általánosítás alól. Azonban az újabb kísérletek eredményeire hivatkozva (I. Onea 2007) arra is felhívja a figyelmet, hogy ha a magyar strukturális fókusz kimerítő olvasata nem kötelező, akkor a magyar nyelvre is vonatkozik a fenti általánosítás. Skopeteas-Fanselow (2011) ezt a feltevést tesztelte görög, spanyol, német és magyar nyelvi adatokra. A magyar nyelvre vonatkoztatva az volt a hipotézisük, hogy Zimmermann (2008) általánosítása nem teljesül a magyar nyelvre, mivel első kísérletük eredményei azt mutatták, hogy a kimerítő olvasat kötelező. Tehát a második kísérletben a tesztmondatok fókuszált összetevői, azaz a strukturális fókuszban álló tárgyi szerepű konstituensek referensei vagy előrejelezhetőek (pl. (3) esetén pisztráng), vagy meglepőek (pl. (3) esetén üvegpalack) az adott szituációban. Az eredmények alátámasztották kiinduló hipotézisüket, azt, hogy a strukturális fókusznak a magyarban szemantikai tulajdonsága a kimerítő olvasat: olyan tulajdonság, amely nem érzékeny arra, hogy a fókuszba kerülő elem mennyire illeszkedik a világtudásunkhoz, azaz mennyire előrejelezhető vagy várt az adott szituációban.

Mindazonáltal megjegyzendő, hogy a szerzők nem tették közzé a vizsgált magyar mondatok listáját tanulmányukban, ami elbizonytalaníthat bennünket a következtetéseik érvényessége tekintetében, hiszen az első kísérletben használt mondatok is jelöltek voltak. Ezért kísérletük végkövetkeztetése, hogy ti. a vizsgált nyelvek közül a magyar az egyetlen nyelv, amelyben a kimerítőség strukturális tulajdonság, valamint az, hogy a strukturális fókusz kimerítősége nem érzékeny a közölt információ előrejelezhető, illetve meglepő voltára, legalábbis felülvizsgálatra szorul.

\subsection{Korábbi kísérletes munkák a szintaktikailag jelöletlen fókusz természetéröl}

Elméleti szempontból Surányi (2011) tanulmánya kérdés-szemantikai keretben tárgyalta és vetette össze a strukturális fókusz és a szintaktikailag jelöletlen fókusz kimerítő értelmezésének különböző aspektusait. Surányi (im.) fenntartja, hogy a strukturális fókusz kimerítősége szemantikai természetű; tehát a kimerítő értelmezés független attól, hogy milyen típusú kérdésre adott válaszban jelenik meg („Említs legalább egyet!”, „Említsd mindet!”). Ezzel szemben a szintaktikailag jelöletlen fókuszról megállapítja, hogy kimerítősége a megválaszolt kérdés függvénye, és ezt a fajta kimerítőséget pragmatikai kimerítőségnek nevezi. Ebben a megközelítésben a szintaktikailag jelöletlen fókusz értelmezését tehát befolyásolja az, hogy milyen típusú kérdésre adott válaszban szerepel. Továbbá az is lehetséges, hogy egy kiegészítendő kérdésre adott válasz nem az expliciten feltett kérdés fókuszkonstituensével kongruens, hanem egy implicit, a válaszadó által módosított Épp Tárgyalt Kérdésre (ÉTK) felel, ami tágabb fókuszkonstituenst tartalmaz. Ezekben az esetekben a válasz is tágabb fókuszú, mint amit az explicit kérdésre adott választól elvárnánk, azonban a módosított ÉTK-ra adott válasz az eredeti, explicit kérdésre is tartalmazza a választ. Fontos megjegyezni, hogy ha egy „Említsd mindet!" kérdésre, azaz egy olyan kérdésre válaszolunk, amikor a kérdés preszupponálja, hogy a benne lévő predikátum pontosan egy entitásra igaz, akkor a szűk fókuszú szintaktikailag jelöletlen fókuszt tartalmazó válasz elfogadhatósága 
marginális, hiszen a strukturális fókuszt tartalmazó válasz elérhetősége blokkolja a szintaktikailag jelöletlen fókusz kimerítő értelmezését. A tág VP fókuszt tartalmazó válasz azonban kongruens válasz lehet a módosított Épp Tárgyalt Kérdésre, és ilyenkor a tág fókuszú válasz pragmatikailag kimerítő értelmezést nyerhet. Ez azt jelenti, hogy fontos különbség van a strukturális és a szintaktikailag jelöletlen tág fókusz kimerítősége között: míg a strukturális fókusz kimerítősége szemantikai, addig a tág fókuszú szintaktikailag jelöletlen fókusz kimerítősége pragmatikai.

Destruel et al. (2015) felfogását alapul véve úgy véljük, hogy a strukturális és a szintaktikailag jelöletlen fókusz közti különbségtétel megragadható egy másik perspektívából is. Destruel et al. (2015) amellett érvelnek, hogy egy kérdésre adott válasz akkor tekinthető maximálisnak, ha „egyetlen más igaz válasz sincs az épp tárgyalt kérdésre, amelyik [...] erősebb lenne"7 (Destruel et al. 2015: 136). A maximális válaszok tehát kimerítőek, hiszen nem követheti őket további olyan kérdés, amelyik olyan entitás(ok)ra vonatkozna, amely(ek) szintén kielégítő választ ad(nak) a megelőző kérdésre. A (4) példában szereplő második kérdés például nem helyénvaló, legalábbis ha elfogadjuk, hogy a beszélő és a hallgató ugyanazzal a háttérfeltevéssel rendelkezik, mint a kisgyermekes szülök általában: a háttérfeltevés tehát az, hogy amikor esti mesét olvasunk fel a gyermekeinknek, akkor egy este általában egyetlen mesét szoktunk felolvasni. Tehát, a kérdés egy ilyen szituációban furcsának tünik, mivel egy strukturális fókuszt tartalmazó, kimerítő választ követően hangzik el.

(4) Kérdés: Mit olvastál fel nekik elalvás előtt?

Válasz: A Hamupipőkét olvastam fel.

\# És még mit olvastál fel nekik?

Mivel a szintaktikailag jelöletlen fókusz (tág fókusz) esetében a kimerítőség opcionális, ezért az alábbi (5) példában szereplő második kérdés sokkal inkább elfogadható, mint (4) esetében:

(5) Kérdés: Mit olvastál fel nekik elalvás előtt? ${ }^{8}$

Válasz: Felolvastam a Hamupipőkét.

És még mit olvastál fel nekik?

(A kérdés-válasz párok forrása Surányi 2011: 283)

Empirikus perspektívából nézve fontos ehelyütt feleleveníteni Gerőcs et al. (2014) két kísérletét. Az első kísérletben a strukturális és a szintaktikailag jelöletlen fókusz kimerítőségét tesztelték. A másodikban két további fókuszstruktúrát is górcső alá vettek: a csak partikulával módosított fókuszt, valamint a szétszakított szerkezetet (cleft).

Első kísérletük kiindulópontját az a relevanciaelméleti feltevés képezte, melynek értelmében a kognitív források korlátozása együtt jár az információfeldolgozás minőségének csökkenésével. A strukturális és a szintaktikailag jelöletlen fókusz

7 „no true answer to the question under discussion [...] is strictly stronger”.

${ }^{8}$ A példában, ha a kérdésre adott válasz szűk fókuszú, akkor az nem, vagy csak marginálisan elfogadható, mivel, mint arra már fentebb utaltunk, a strukturális fókusz elérhetősége blokkolja a (5)-ben lévő válasz kimerítő értelmezését. Azonban a tág fókuszú pragmatikai kimerítőség elérhető. 
értelmezésére nézve ez azt jelenti, hogy amennyiben a strukturális fókusz kimerítősége szemantikai tulajdonság, úgy azt még akkor is feldolgozza az elme, ha a kognitív források erőteljesen limitáltak egy kísérleti szituációban. Ha azonban a kognitív források nincsenek korlátozva a kísérletben, akkor pragmatikai implikatúra is létrejöhet, azaz nem kizárólag a strukturális, hanem a szintaktikailag jelöletlen fókusznak is lehet kimerítő olvasata. A kognitív források korlátozását a résztvevők számára rendelkezésre álló időkeret beállításaival valósították meg a kísérletben.

A kísérleti feladat elején a résztvevők egy háttértörténetet hallgattak meg (eszerint egy fiatal lány talál egy hullát, és a hulla zsebében egy papírlapot), melyet kiegészítendő kérdések követtek. Ezután a kísérlet tárgyát képező kérdés-válasz párt hallották, és ezzel egyidőben megjelent a képernyőn egy kép, amely egy nem kimerítő szituációt mutatott be. Ha a kép illeszkedett az elhangzott válaszhoz, akkor a résztvevőnek igen-nel kellett válaszolnia. Ellenkező esetben, vagyis amikor a kép nem illeszkedett a válaszhoz, akkor nem-mel kellett válaszolni - ami a kimerítő értelmezés jelenlétét volt hivatva megjeleníteni. A résztvevőket két csoportra osztották, mégpedig az időkeret hossza alapján: a Hosszú kondíció résztvevőinek 3000 ms állt rendelkezésükre a válaszadásra, míg a Rövid kondíció résztvevőinek kevesebb, csupán 1000 ms. Alább egy tesztelem Gerőcs et al. tanulmányából (Gerőcs-Babarczy-Surányi 2014: 186):

Kérdés: Mit karikázott be az áldozat?

Válasz (strukturális fókusz): Az áldozat a piramist karikázta be.

Válasz (szintaktikailag jelöletlen fókusz): Az áldozat bekarikázta a piramist.

A monitoron megjelenő képen egy holló, egy hal és egy piramis volt látható, a holló és a piramis külön-külön volt bekarikázva.

Gerőcs et al. (2014) azt figyelték meg a Hosszú kondícióban, hogy a strukturális és a szintaktikailag jelöletlen fókuszt tartalmazó mondatoknál a résztvevők körülbelül ugyanolyan arányban válaszoltak nem-mel (kimerítő értelmezés: 63\% és 72\%). A szerzők szerint ez az eredmény a bevezető kiegészítendő kérdés hatásának tudható be, amely elősegítette a kimerítő olvasat létrejöttét. A rövidebb időkeret kevesebb nem választ eredményezett, és a résztvevők mindkét fókusztípus esetében a véletlen szintjéhez közel teljesítettek. Ez az eredmény Gerőcs et al. (2014) szerint egyfelöl magyarázható azzal a feltételezéssel, hogy a Rövid kondícióban a rendelkezésre álló idő nem volt elegendő a vizsgált mondatok feldolgozásához, és ezért a résztvevők csak találgattak. Másfelől azzal a feltevéssel is magyarázhatóak az eredmények, hogy a kimerítő értelmezés implikatúraként jelenik meg mind a strukturális, mind pedig a szintaktikailag jelöletlen fókusz esetében. Anélkül, hogy tüzetesebben is megvizsgálnánk, hogy melyik feltevés plauzibilisebb, fontos megjegyezni, hogy mindkét magyarázat abba az irányba mutat, mely szerint a strukturális fókusz kimerítősége nem szemantikai természetű.

A szerzők ennek a feltevésnek a további vizsgálatára egy második kísérletet is elvégeztek. Ebben is a strukturális fókuszt vetették össze más fókusztípusokkal, mint például a szintaktikailag jelöletlen fókusz, a csak partikulával módosított fókusz, valamint a szétszakított szerkezet (cleft): 
a. A kalapot próbálta fel.

b. Felpróbálta a kalapot.

c. Csak a kalapot próbálta fel.

d. A kalap volt az, amit felpróbált. (Gerőcs-Babarczy-Surányi 2014: 189)

A szerzők előzetes elvárása az volt, hogy a strukturális fókusz, a csak-fókusz és a szétszakított szerkezet preferáltan kimerítő olvasatú lesz, míg a szintaktikailag jelöletlen fókusz esetén kevésbé valószínű a kimerítő olvasat, tekintve, hogy a tesztben csak izolált mondatok szerepeltek.

A résztvevők először bevezetésképpen megismerkedtek egy történettel, amely egy tolvajról szólt, akit üldöznek a rendőrök. Míg a képernyőn egy szemtanú leírását olvasták a tolvajról, a résztvevők négy egyén képét is látták. A feladatuk az volt, hogy kiválasszák azt vagy azokat a kép(ek)et, amelyek a leginkább illenek a személyleíráshoz. Minden tesztmondathoz egy kimerítő és egy nem kimerítő kép társult, továbbá két disztraktor.

Az eredmények szignifikáns különbséget mutattak bármelyik két fókusztípus között: a csak-fókusz bizonyult kimerítő értelműnek a legtöbbször, míg a szintaktikailag jelöletlen fókusz esetén csak nagyon alacsony arányú volt a kimerítő értelmezés. A strukturális fókusz és a cleft-mondatok között meglepő módon szintén szignifikáns eltérés volt, az utóbbi szerkezeteket gyakrabban értelmezték kimerítő módon (35 vs. 54\%) a résztvevők. Mivel a szétszakított szerkezetek kimerítőségét következményes jelentéstartalomnak tekinthetjük, a szerzők azt feltételezik, hogy a strukturális fókusz kimerítősége nem szemantikailag kódolt tulajdonság, ennélfogva inkább konvencionális implikatúraként írható le. Ami a szintaktikailag jelöletlen fókuszt illeti, a kísérlet azt a nézetet erősítette meg, amely szerint a szintaktikailag jelöletlen fókusz kimerítősége kontextuális tényezők hatására jön létre, hiszen az előző kísérletben sokkal nagyobb arányban kapott kimerítő értelmezést. Ez azonban felveti azt a kérdést, hogy van-e valamilyen különbség a szintaktikailag jelöletlen fókusz és a strukturális fókusz kimerítősége között, hiszen, ha a strukturális fókusz kimerítősége konvencionális implikatúraként írható le, ahogyan azt a szerzők javasolják, akkor ez egyúttal azt is jelenti, hogy a strukturális fókusz kimerítősége bizonyos mértékig kontextusfüggő.

\section{A kísérlet}

Kísérletünk megtervezésekor az volt a célunk, hogy a strukturális fókuszt és a szintaktikailag jelöletlen fókuszt tartalmazó, fentebb tág VP fókuszúnak nevezett válaszok kimerítő értelmezését ugyanabban a kísérleti dizájnban hasonlítsuk össze. ${ }^{9}$ Ennek megfelelően a kísérlet során két kérdést vizsgáltunk:

(i) azt, hogy a magyar anyanyelvü beszélők egyaránt magasabb értékítéletet adnak-e a kimerítő olvasatot támogató szituációkban a kétféle fókuszstruktúrának, mint a nem kimerítő szituációkban;

${ }^{9} \mathrm{~A}$ továbbiakban szintaktikailag jelöletlen fókusz alatt, ha azt külön nem jelezzük, tág fókuszt értünk. 
(ii) azt, hogy a szóban forgó, jelöltnek tekinthető struktúrák magasabb ítéletet kapnak-e akkor, amikor a jelölt struktúra használatát a fókuszban lévő konstituens nem várt, a világismeretünk tükrében meglepő státusza motiválja.

A kísérlet tehát két tényezőre, a KIMERíTŐ és VÁRT faktorok tesztelésére irányult. A következő részben ezen két faktornak a kísérletben használt definícióját ismertetjük.

Kamp (2008) kontextusokra vonatkozó Riester (2008) által idézett klasszifikációjára támaszkodva azt mondhatjuk, hogy egy artikulált kontextus négy részből áll. Ezek a dinamikus diskurzus kontextus, a környezeti kontextus, az általános kontextus és az enciklopédikus kontextus. Mivel a kísérletben csupán kérdés-válasz párokat használtunk, ezek közül a dinamikus diskurzus kontextus és az általános kontextus nem releváns a vizsgálat szempontjából. A környezeti kontextus a közvetlen fizikai környezet összes entitását magába foglalja, míg az enciklopédikus kontextus „azon entitásokat tartalmazza, amelyekről a beszélő feltételezheti, hogy a hallgató hétköznapi tudással bír róluk"10 (Riester 2008: 517). Ezen felül, az enciklopédikus kontextus az adott entitásokhoz kapcsolódó, igen széles spektrumon mozgó információkat is tartalmaz. Kísérletünkben kimerítő és nem kimerítő szituációkat különböztettünk meg, attól függően, hogy a környezeti kontextus mely entitás(ai) szolgáltak a cselekedetek pácienseiként az adott szituációt megjelenítő képeken. Ez azt jelenti, hogy egy adott szituációt akkor tekintettünk kimerítőnek, amikor a képen csak a fókuszkonstituens által referált entitás szerepelt páciensként.

A VÁRT faktor definícióját illetően Destruel-Velleman (2014) fentebb említett, a világról alkotott ismereteinkre vonatkozó definíciójára támaszkodtunk annak érdekében, hogy Zimmermann (2008) felvetését empirikusan teszteljük a magyar nyelvre vonatkoztatva. Ennek alapján egy adott esemény leírásakor a világtudásunkhoz képest várt és nem várt pácienseket különböztethetünk meg. Egy páciens akkor tekinthető (nem) vártnak, amikor az adott eseményben való megjelenése a világtudásunk alapján (nem) kompatibilis a kérdéses eseményről alkotott általános feltevéseinkkel. A kísérletben olyan megnyilatkozások szerepeltek, amelyekben a várt és a nem várt páciensek fókuszpozícióban voltak.

A fent ismertetett két faktor, és a kétféle fókuszstruktúra tesztelésére $2 \times 2 \times 2$ kevert-faktoriális dizájnt használtunk. Egyrészt volt egy csoportok közötti változónk, a FÓKUSZ TíPUSA: strukturális fókusz vs. szintaktikailag jelöletlen fókusz. Ennek megfelelően a résztvevők egy csoportja csak strukturális fókuszt, míg a másik csoport csak szintaktikailag jelöletlen fókuszt tartalmazó megnyilatkozásokat kapott. Másrészt, volt két csoporton belüli változónk is, egyenként két-két szinttel: a KIMERÍTŐ faktor szintjei: kimerítő és nem kimerítő szituáció, míg a VÁRT faktor szintjei: várt és nem várt páciensek fókuszban. Mind a négy kondícióban öt itemet prezentáltunk az alanyoknak, azaz ötféle szituációban jelent meg négy-négy különböző kép. Egy-egy szituáción belül a VÁRT faktor szintjei mentén más-más válasz szerepelt, például az alábbi képek esetén a várt páciens a hal, míg a nem várt páciens a nyaklánc volt. A résztvevők összesen húsz kérdés-válasz párt hallottak, és volt 12 töltelék kérdés-válasz párunk is.

10 "consists of the entities that the speaker may assume his addressee to have knowledge about". 
A kísérlet négy kondícióját az alábbi ábra szemlélteti:

1. kondíció: kimerítő képtípus várt pácienssel fókuszpozícióban

2. kondíció: nem kimerítő képtípus várt pácienssel fókuszpozícióban

3. kondíció: kimerítő képtípus nem várt pácienssel fókuszpozícióban

4. kondíció: nem kimerítő képtípus nem várt pácienssel fókuszpozícióban
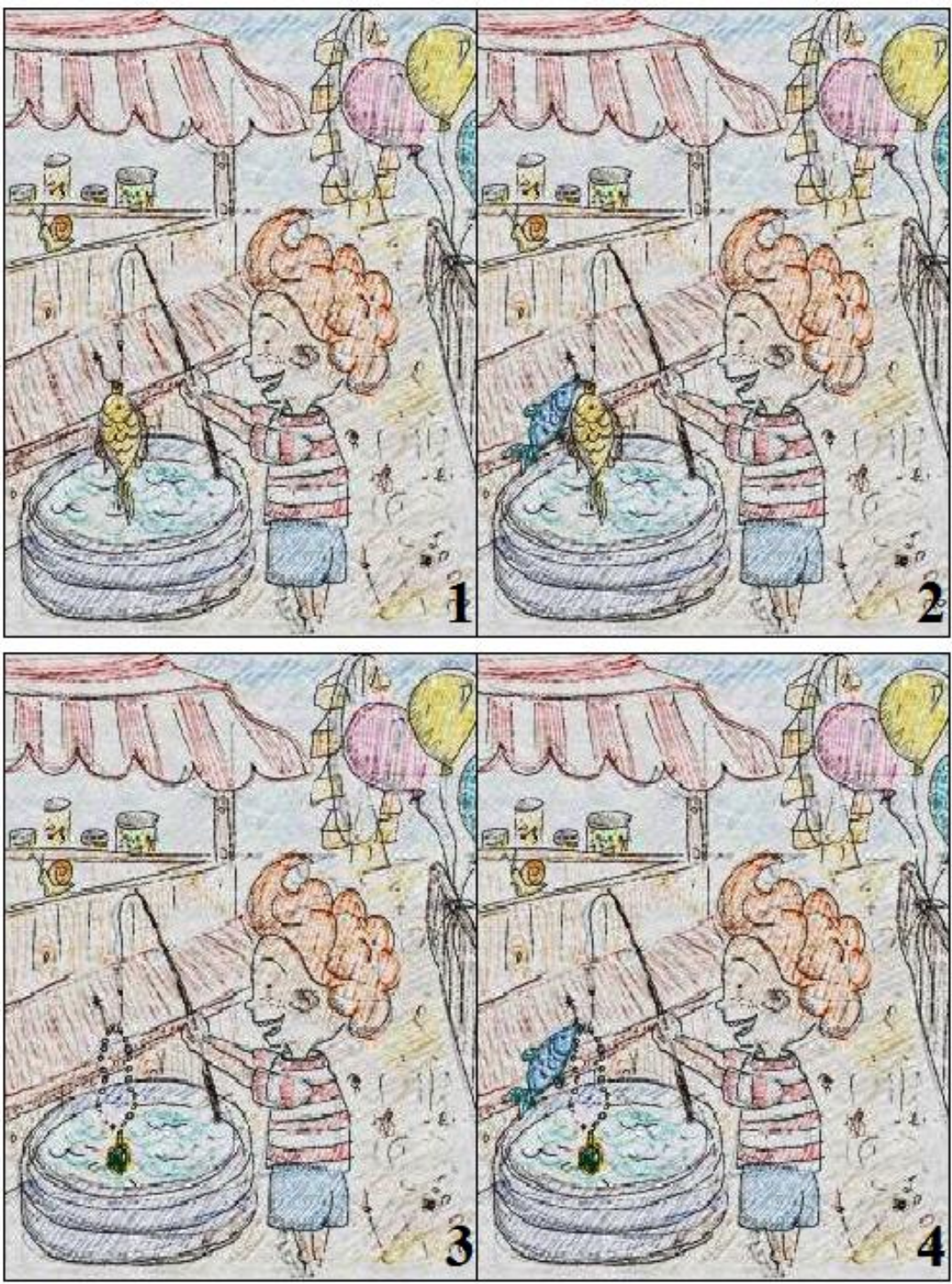

1. ábra

A vizsgált kondíciók 
A (8)-as példa egy-egy tesztmondatot mutat be az 1. kondícióban, mindkét fókusztípust szemléltetve, a résztvevők a válasz és a kép megfelelőségét értékelték egy hatfokozatú skálán:

(8) Kérdés: Mit fogott ki Bence?

Válasz: Bence egy halat fogott ki. (strukturális fókusz)

Válasz: Bence kifogott egy halat. (szintaktikailag jelöletlen fókusz)

\subsection{Módszer}

A kísérletben mondat-kép megfeleltetési feladatot használtunk, ahol a képek megjelenése után az alanyok egy rövid dialógust hallottak. A kép része volt egy háttérinformációt közlő mondat is, amelyet a kép részeként láthattak a résztvevők (Bence a vidámparkban a horgászmedencénél játszott). Tehát a résztvevők először ezeket a rövid feliratokat olvashatták, amíg a képet tanulmányozták. Ezután következett a hangzó inger, egy kérdés-válasz pár. A kísérlet tervezése során kiemelt jelentőséget tulajdonítottunk a hangzó stimulusok használatának, hiszen ezek fontos szerepet töltenek be a vizsgált fókuszstruktúrák feldolgozásában. A kérdés-válasz pár megnyilatkozásait két magyar anyanyelvi beszélővel rögzítettük, annak érdekben, hogy a hangzó inger minél természetesebb legyen. A strukturális fókuszt tartalmazó válaszokban az ige előtti összetevő volt a legprominensebb, míg a szintaktikailag jelöletlen fókuszt tartalmazó válasz prozódiailag semleges hangsúlyszerkezetű volt (vö. Surányi 2011). A kísérlet résztvevői egyszer hallgatták meg a dialógust, mialatt az adott szituációt reprezentáló képet is látták. A feladatuk az volt, hogy a válasz elfogadhatóságát egy hatfokozatú Likert-skálán (1: teljesen elfogadhatatlan, 6: teljesen elfogadható) ${ }^{11}$ ítéljék meg. A kísérlet alanyai időbeli megszorítás nélkül egy laptop megfelelő billentyűjének lenyomásával jelezték az általuk megfelelőnek tartott értékítéletet. A kísérlet kivitelezésekor a Daniele Panizza által fejlesztett Pypres eszközrendszert használtuk, a tesztelt elemek egyénenként randomizált sorrendben jelentek meg az alanyok számára a laptopon.

\subsection{Résztvevők}

A kísérletben összesen 66 anyanyelvi beszélő vett részt, mindannyian egyetemi hallgatók voltak, akik a kísérlet elvégzése előtt semmilyen nyelvészeti képzésben nem részesültek. A részvevőket véletlenszerűen választottuk ki és véletlenszerűen soroltuk be őket a két csoportba. A résztvevők további adatait az alábbi táblázat tartalmazza. A kísérlet befejezése után minden résztvevő apró ajándékot kapott.

\begin{tabular}{lllll}
\hline & Férfi & Nő & Összesen & Átlagéletkor \\
\hline 1. csoport: (strukturális fókusz) & 14 & 18 & 32 & 22 \\
2 csoport: (szintaktikailag jelöletlen fókusz) & 13 & 21 & 34 & 21
\end{tabular}

1. táblázat

\footnotetext{
${ }^{11}$ Azért döntöttünk a hatfokozatú Likert-skála használata mellett, mert - mint Pintér (2016) megmutatta -, a bináris választást tartalmazó feladatok nem alkalmasak a strukturális fókusz kimerítőségének vizsgálatára.
} 


\subsection{Eredmények}

Kísérletünk átfogó leíró statisztikai eredményeit az alábbi 2. táblázat és a 2. ábra tartalmazza. Az ábrákon a hibavonalak a 95\%-os konfidencia intervallumot jelölik. A 2. ábrán jól látható, hogy a két fókuszstruktúra igen hasonló értékítéleteket kapott mind a négy kondícióban:

\begin{tabular}{llll}
\hline & fókusz típusa & átlag & szórás \\
\hline \multirow{2}{*}{ kimerítő, várt } & strukturális & 5,69 & 0,74 \\
& jelöletlen & 5,8 & 0,41 \\
\multirow{2}{*}{ kimerítő, nem várt } & strukturális & 5,4 & 0,83 \\
\multirow{2}{*}{ nem kimerítő, várt } & jelöletlen & 5,61 & 0,58 \\
& strukturális & 3,03 & 0,88 \\
\multirow{2}{*}{ nem kimerítő, nem várt } & jelöletlen & 3,36 & 0,92 \\
& strukturális & 3,14 & 0,85 \\
& jelöletlen & 3,36 & 0,96 \\
\hline
\end{tabular}

2. táblázat

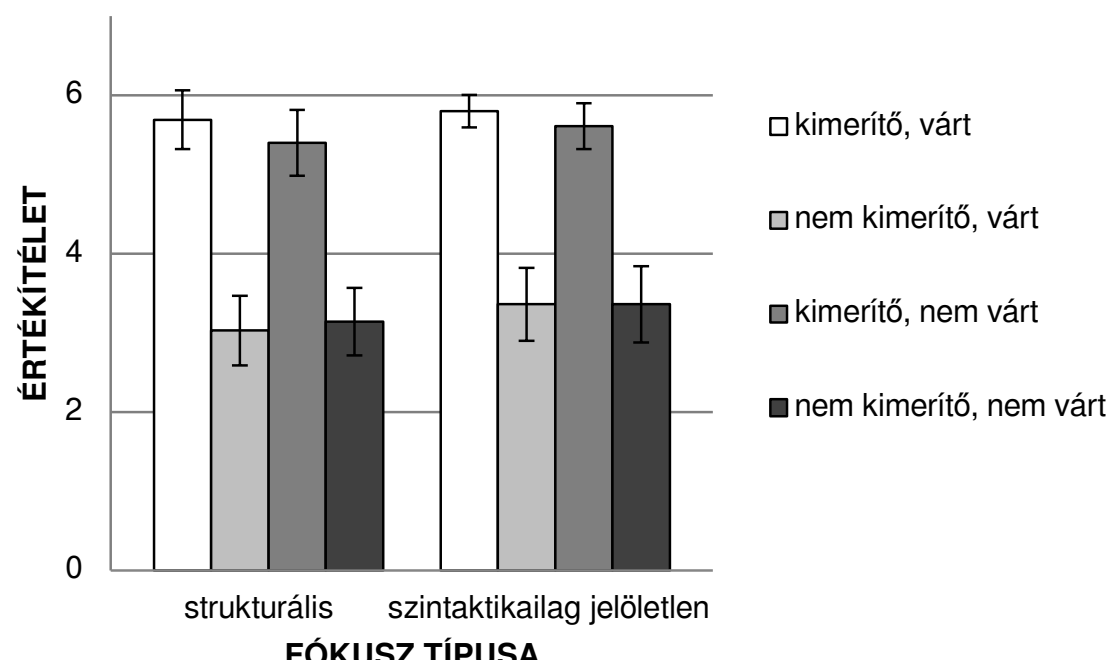

2. ábra

Az eredmények áttekintése

A kevert modell ANOVA elemzés alapján a KIMERÍTŐ faktornak főhatása van ( $\mathrm{F}(1$, $\left.64)=406,9, p<0,001, \eta_{p}{ }^{2}=0,864\right)$, azaz, ha eltekintünk attól, hogy melyik fókuszstruktúráról van szó, illetve attól, hogy a referált entitás várt vagy nem várt, akkor kimerítő szituációban a válaszok szignifikánsan nagyobb értékítéleteket kaptak, mint nem kimerítő szituációban. A KIMERíTŐ faktor főhatása a 3. ábrán látható. 


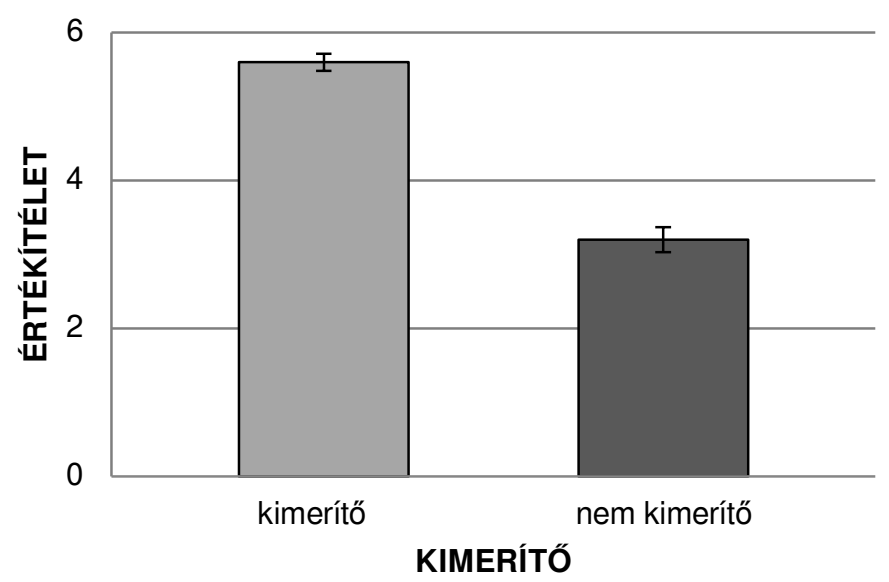

3. ábra

A KIMERITŐ faktor főhatása

A VÁRT faktor nem befolyásolta az értékítéleteket (vö. 4. ábra), vagyis fókuszpozícióban a várt/nem várt páciensek hasonló átlagos értékítéletet kaptak $(F(1,64)$ $=3,614$, nem szignifikáns: $\left.p=0,062, \eta_{p}^{2}=0,053\right)$. A FóKUSz TíPUSA faktornak szintén nincs hatása $\left(F(1,64)=2,573\right.$, nem szignifikáns: $\left.p=0,114, \eta_{p}{ }^{2}=0,039\right)$, azaz, ha minden egyéb faktortól eltekintünk, a strukturális fókuszt és a szintaktikailag jelöletlen fókuszt tartalmazó megnyilatkozások tulajdonképpen ugyanolyan értékítéleteket kaptak (vö. 5. ábra). Az alábbi ábrákon jól látszik, hogy a két utóbbi faktornak nincs hatása.

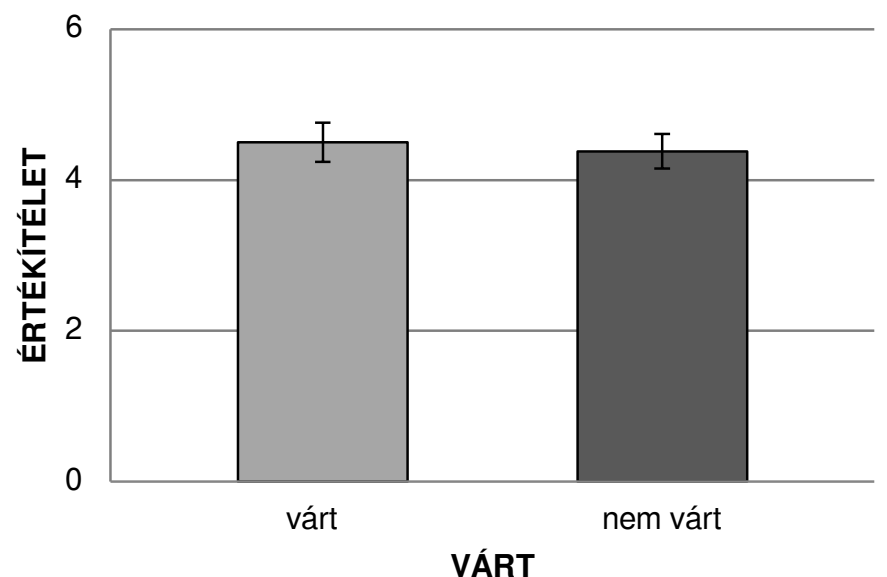

4. ábra

A VÁRT faktornak nincs hatása 


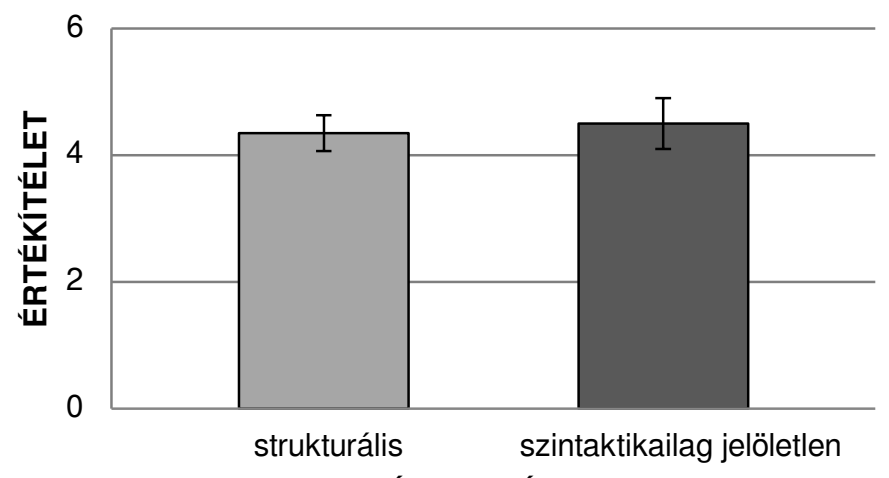

FÓKUSZ TíPUSA

\section{5. ábra \\ A FókUSZ TíPUSA változónak nincs hatása}

Szignifikáns interakciót találtunk a KIMERíTŐ és a VÁRT faktor között $(F(1,64)=9,32$, $p<0,05, \eta_{p}^{2}=0,127$ ), azaz szignifikáns eltérés tapasztalható a várt és a nem várt tesztelemekre adott átlagos értékítéletek között a KIMERíTö faktor két szintjén, mindkét vizsgált struktúrára nézve (I. 6. és 7. ábra). Ahogy az ábrákon látható, kisebb eltérés tapasztalható a kimerítő és a nem kimerítő kondíciók között abban az esetben, ha a fókuszpozícióban lévő páciens nem várt, mint akkor, amikor várt. Az interakció erősebbnek tünik a strukturális fókusz esetében ${ }^{12}$ (a várt kondícióban a kimerító és a nem kimerítő kontextusokra adott átlagos értékítéletek különbsége a strukturális fókusznál 2,66, míg a szintaktikailag jelöletlen fókusznál ugyanez az eltérés 2,44; a nem várt kondícióban ez a különbség 2,26, illetve 2,25). Azonban az interakció gyenge, az értékítéletek totális variabilitásának csak 12,7 százalékáért felelős.

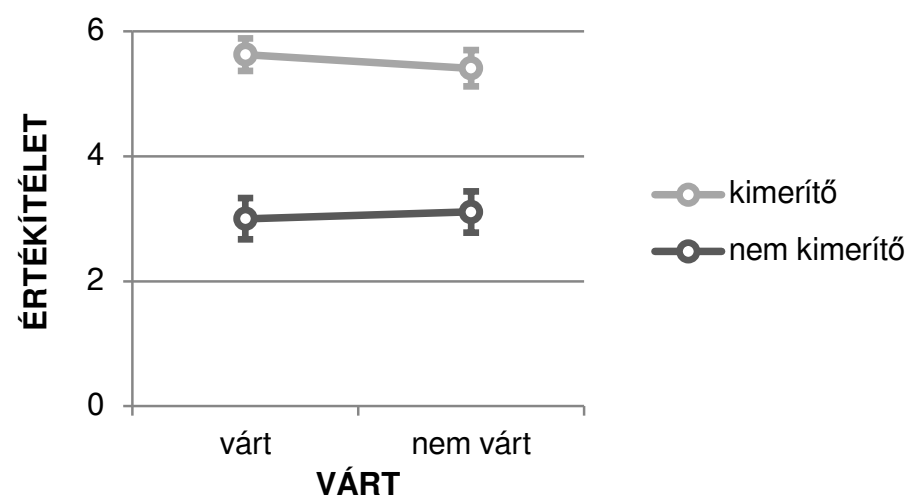

6. ábra

A KIMERITŐ és a VÁRT faktor interakciója a strukturális fókusz kondícióban

${ }^{12}$ Nem detektáltunk azonban szignifikáns hármas (fókusz típusa $\times$ KIMERÍTŐ $\times$ VÁRT) interakciót: $F(1,64)=1,119$, nem szignifikáns: $p=0,294)$. 


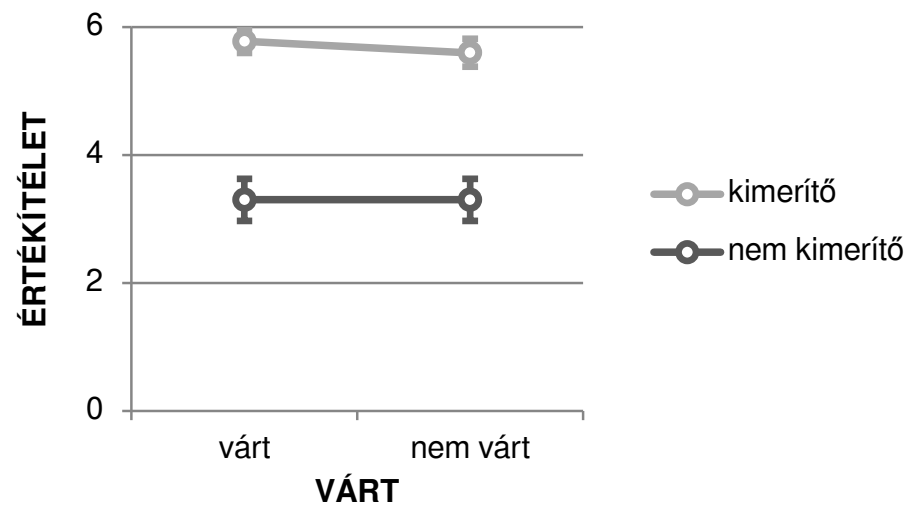

7. ábra

A KIMERÍTŐ és a VÁRT faktor interakciója a szintaktikailag jelöletlen fókusz kondícióban

\subsection{Diszkusszió}

Összefoglalva, a KIMERíTŐ faktor főhatással bírt, vagyis szignifikáns eltérést találtunk a kimerítő és a nem kimerítő kontextusok között, ha a többi változótól eltekintünk. A kimerítő kontextusban az értékítéletek átlaga igen magas, 5,5 fölötti a hatfokozatú skálán, míg a nem kimerítő kontextusban megfigyelhető egyfajta elbizonytalanodás, hiszen az értékek a hatfokozatú skála közepére esnek, az értékek átlaga éppen meghaladja a hármas értéket. Ezek az eredmények összhangban vannak Gerőcs et al. (2014) megállapításaival, miszerint a kiegészítendő kérdés jelenléte első kísérletükben mind a strukturális, mind a szintaktikailag jelöletlen fókusz esetében a kimerítő olvasat magasabb arányú előhívását eredményezte. Fontos azonban hozzáfüzni, hogy bár a résztvevők a válaszok elfogadhatóságát értékelték, tulajdonképpen ez nem leválasztható a kiegészítendő kérdésnek egy adott szituációban történő értelmezéséről, vagyis az ÉTK-nak a befogadó általi esetleges módosításáról, valamint az ÉTK és a válasz illeszkedéséről. Ez azt jelenti, hogy a kimerítő szituáció valóban támogatta a kérdés-válasz esetén a kimerítő olvasat előhívását (I. 1. ábra 1 és 3 kép), míg a nem kimerítő szituáció esetén (I. 1. ábra 2 és 4 kép) az ÉTK és a rá adott válasz nincs összhangban a kép által reprezentált szituációval.

További kutatást igényel annak a kérdésnek a vizsgálata, hogy mennyire marad prominens a kimerítő olvasat a kiegészítendő kérdés jelenléte nélkül, hiszen jogos az a feltételezés, hogy a kimerítő olvasatot a kérdés jelenléte, a prozódiai inger által felkínált többletinformáció, illetve ennek a két tényezőnek az összjátéka bizonyos mértékben támogatta. A probléma tesztelésére utánkövető kísérlet elvégzését tervezzük, melynek során ugyanezen ingereket használjuk majd a kiegészítendő kérdés nélkül. Az eredmények összevetése után még pontosabb képet alkothatunk a két struktúra értelmezéséről. Az utánkövető kísérlet eredményei a strukturális fókusz kimerítőségéről szóló, jelenleg is zajló tudományos vitához is hozzájárulhatnak. Például Kas-Lukács (2013) kísérletének eredményei, amelyben mondatkép megfeleltetési feladatot alkalmaztak igaz/hamis ítéletekkel, megkérdőjelezték a strukturális fókusz kimerítőségét. Azonban, ahogy azt a szerzők is megjegyzik, még 
a felnőtt résztvevők között is igen jelentős egyéni variabilitás mutatkozott. Ahogy azt már fentebb említettük, Pintér (2016) amellett érvel, hogy a bináris ítéleteken alapuló feladatok nem elég kifinomultak, és így nem alkalmasak arra, hogy a strukturális fókusz kimerítőségét ennek alapján teszteljük. Vagyis a Kas-Lukács (2013) eredményeiben megmutatkozó egyéni variabilitás a feladat természetéből is adódhat; a strukturális fókusz kimerítőségének jellege továbbra is nyitott kérdés.

Úgy véljük, hogy ennek a kísérletnek az egyik legfontosabb eredménye az, hogy két különböző fókuszstruktúra, amit elméleti szempontból többen is egymást kizáró tulajdonságokkal jellemeztek, ugyanabban a dizájnban meglepően hasonló viselkedést mutat. A kapott eredmények (I. 2. táblázat) visszaigazolják azt, hogy egy „Említsd mindet!” kérdés és a strukturális fókuszt tartalmazó válasz együttese tökéletesen elfogadható kimerítő szituációban. A szintaktikailag jelöletlen fókuszról annyit árul el a kísérlet, hogy a tág fókuszt tartalmazó mondat valóban jól elfogadható egy „Említsd mindet!” kérdésre adott válaszként kimerítő szituációban, és a kérdés-válasz pár jól illeszkedik a kép által megjelenített kimerítő szituációhoz. Vagyis az eredmények megerősítik Surányi (2011) azon megállapítását, hogy a szintaktikailag jelöletlen fókusz tág fókuszként való értelmezése lehet pragmatikailag kimerítő.

Kísérletünk adatai végeredményben megerősítik azt a széles körben elfogadott nézetet, amely szerint a strukturális fókuszt tartalmazó mondatokat, amelyek kiegészítendő kérdést válaszolnak meg, kimerítő módon interpretáljuk. Ezekben az esetekben a kiegészítendő kérdés tulajdonképpen egy kérést fejez ki a hallgató felé, és a beszélő elvárása az, hogy a válasz majd megadja mindazon entitások pontos részhalmazát, amelyek kielégítik a kérdésben szereplő predikátumot, azaz a válasz bizonyos értelemben maximális válasz lesz (vö. Balogh 2009; Surányi 2011; Destruel et al. 2015). Azonban ezen a ponton nem világos, hogy a kimerítő olvasat egy előfeltételezett jelentéstartalom előhívásának (I. Pintér 2016), egy konvencionális implikatúrának (Gerőcs-Babarczy-Surányi 2014) vagy egy skaláris implikatúrának (Babarczy-Balázs 2016) az eredményeképpen jön létre. Ezek a következtetések, amelyek egymástól részben vagy egészében véve különböző dizájnban lefolytatott kísérletek eredményei alapján jöttek létre, mindazonáltal egyaránt abba az irányba mutatnak, hogy a kimerítőség minden valószínűség szerint nem inherens tulajdonsága a strukturális fókusznak.

Az általunk vizsgált másik tényezőre nézve pedig azt állapíthatjuk meg, hogy a VÁRT faktornak nincs hatása, azaz nem számít, hogy a beszélő a fókuszban lévő pácienst vártnak vagy nem vártnak tekinti a hallgató szempontjából nézve, vagyis nem teljesül az a hipotézis, hogy a világismeretünkhöz képest meglepő információ jelölt struktúrában való megjelenítése elfogadhatóbbá tenné a megnyilatkozást a hallgató számára, mint egy ugyanilyen struktúrában megjelenő várt elem. Pontosabban, azt vártuk volna, hogy ha fennáll Zimmermann (2008) azon nyelvek közti feltevése, miszerint a jelölt struktúra használatát motiválja a közölt információ meglepő volta, akkor a strukturális fókusz és a szintaktikailag jelöletlen fókuszt tartalmazó, semleges intonációjú megnyilatkozások között érzékelhető különbségnek kellett volna lennie az értékítéletek között a VÁRT faktor két szintjén. SkopeteasFanselow (2011) szintén arra a következtetésre jut, hogy a magyar strukturális fókusz interpretációja független attól, hogy a fókuszkonstituens referense előrejelezhető-e vagy sem az adott kontextusban. Mindazonáltal úgy véljük, hogy ennek 
az egy faktornak a tesztelése nem indokolja azt az általánosítást, miszerint a strukturális fókusz és a szintaktikailag jelöletlen fókusz értelmezését egyáltalán nem befolyásolják kontextuális tényezők, hiszen számos olyan kontextuális tényező lehet, amelyet most nem vizsgáltunk, de amelyek szerepet játszhatnak a kérdéses fókuszstruktúrák használatában és értelmezésében. ${ }^{13}$

Fontos még megjegyezni, hogy gyenge interakciót detektáltunk a KIMERíTŐ és a VÁRT faktor között, és az interakció erősebb volt a strukturális fókusz esetében. A gyenge interakció arra utal, hogy a strukturális fókusz értelmezése nem teljesen független a kontextuális faktoroktól, azonban az interakció maga túl marginális ahhoz, hogy ennél erősebb következtetést vonjunk le.

\section{Konklúzió}

Tanulmányunkban egy olyan kísérlet eredményeiről számoltunk be, amelyben a magyar strukturális fókusz és a szintaktikailag jelöletlen fókusz (tág VP fókusz) fókuszértelmezését hasonlítottuk össze ugyanabban a dizájnban. A szintaktikailag jelöletlen fókuszt korábban a releváns irodalomban, a strukturális fókusszal szemben, nem kimerítő olvasatúként aposztrofálták, amíg Surányi (2011) meg nem kérdőjelezte ezt az általánosan elfogadott nézetet. A fentebb bemutatott kísérletünk során Surányi (2011) azon felvetését kívántuk empirikus úton alátámasztani, amely szerint a szintaktikailag jelöletlen fókusz is értelmezhető kimerítően bizonyos esetekben (tág VP fókusz).

Összefoglalásképpen megállapíthatjuk, hogy kísérletünk eredményei alátámasztják Gerőcs et al. (2014) első kísérletének eredményeit, mivel empirikus úton nem volt kimutatható eltérés a strukturális fókusz és a szintaktikailag jelöletlen fókusz értelmezése között akkor, amikor kiegészítendő kérdésre adott válaszban szerepelnek. A kísérletes adatok tulajdonképpen illeszkednek Surányi (2011) megjegyzéséhez, miszerint „a preverbális fókusszal kifejezett jelentés [...] a posztverbális fókusszal kifejezett jelentés speciális esetének mondható" (Surányi 2011: 289).

Közelebbről, mivel mindkét fókuszstruktúra esetében a kimerítő olvasat preferált, legalábbis ha azt egy kiegészítendő kérdés támogatja, Ugyanakkor rá kell mutatnunk arra, hogy ugyanabban a dizájnban a két különböző fókuszstruktúrára adott értékítéletek minden kondícióban tulajdonképpen megegyeznek. Felmerül tehát az a kérdés, hogy az értékítéletek egybeesése vajon ugyanannak az interpretációs hatásmechanizmusnak köszönhető-e, vagy sem. Azaz továbbra is nyitott kérdés, hogy a kimerítő olvasat szemantikai természetü-e.

\footnotetext{
${ }^{13}$ Alberti Gábor (személyes kommunikáció) hívta fel a figyelmünket arra a lehetőségre, hogy a szintaktikailag jelöletlen fókuszt tartalmazó megnyilatkozások elfogadhatóbbnak tünnek olyan szituációkban, amelyekben az evidencialitás is hangsúlyt kap. Például, ha valaki a szemünk láttára véletlenül a kukába dobja a távirányítót, akkor mondhatjuk azt, hogy Nézd már, mit csinált ez a lüke! Kidobta a távirányítót! További kutatásokra van szükség az evidencialitásnak a szintaktikailag jelöletlen fókusz értelmezésében játszott szerepének a feltárásához.
} 


\section{Köszönetnyilvánítás}

A kutatást a Nemzeti Kutatási, Fejlesztési és Innovációs Hivatal (NKFIH) K 111918 nyilvántartási számú projektje (Új megközelítések a magyar névmások nyelvtanának leírásában) és Tóth Enikő részéről az Emberi Erőforrások Minisztériuma ÚNKP-174 kódszámú Új Nemzeti Kiválóság Programja támogatta.

Köszönetünket fejezzük ki Fegyveres Miklósnak a kísérlet lebonyolításában nyújtott segítségéért. Köszönjük Abari Kálmánnak, Alberti Gábornak és Rákosi Györgynek a tanulmány egy korábbi változatához füzött értékes megjegyzéseit.

\section{Hivatkozások}

Babarczy Anna - Balázs Andrea 2016. A kognitív kontroll és a preverbális fókusz értelmezése. In Kas Bence (szerk.) „Szavad ne feledd!” Tanulmányok Bánréti Zoltán tiszteletére. Budapest: MTA Nyelvtudományi Intézet. 151-163.

Balogh, Kata 2009. Theme with Variations. A Context-based Analysis of Focus. Amsterdam: Universiteit van Amsterdam.

Destruel, Emilie - Leah Velleman 2014. Refining contrast: Empirical evidence from the English it-cleft. In Christopher Piñón (szerk.) Empirical Issues in Syntax and Semantics 10. Selected Papers from CSSP 2013. 197-214. http://www.cssp.cnrs.fr/eiss10/.

Destruel, Emilie - Daniel Velleman - Edgar Onea - Dylan Bumford - Jingyang Xue - David Beaver 2015. A cross-linguistic study of the non-at-issueness of exhaustive inferences. In Florian Schwarz (szerk.) Experimental Perspectives on Presuppositions. Berlin: Springer. 135-156. doi:10.1007/978-3-31907980-6 6.

É. Kiss, Katalin 1998. Identificational focus versus information focus. Language 74/2:245-273. doi:10.1353/lan.1998.0211.

Gerőcs, Mátyás - Anna Babarczy - Balázs Surányi 2014. Exhaustivity in focus. Experimental evidence from Hungarian. In Joseph E. Emonds - Markéta Janebová (szerk.) Language Use and Linguistic Structure. Proceedings of the Olomouc Linguistics Colloquium 2013. (Olomouc Modern Language Series 3) Olomouc: Palacký University. 181-194.

Kamp, Hans 2008. Discourse Structure and the Structure of Context. Stuttgart: Universitaet Stuttgart, Institute of Computational Linguistics. https://www.unistuttgart.de/linguistik/sfb732/files/kamp_contexts.020807.pdf.

Kas, Bence - Ágnes Lukács 2013. Focus sensitivity in Hungarian adults and children. Acta Linguistica Hungarica 60/2:217-245. doi:10.1556/ALing.60.2013.2.4.

Kenesei, István 1986. On the logic of word order in Hungarian. In Werner Abraham - Sjaak de Meij (szerk.) Topic, Focus and Configurationality. Amsterdam: John Benjamins Publishing Company. 143-159.

Onea, Edgar 2007. Exhaustivity, focus and incorporation in Hungarian. In Maria Aloni - Paul Dekker - Floris Roelofsen (szerk.) Proceedings of the Sixteenth Amsterdam Colloquium. Amsterdam: ILLC/Department of Philosophy, University of Amsterdam. 169-174. 
Onea, Edgar - David Beaver 2011. Hungarian focus is not exhausted. Proceedings of the 19th Semantics and Linguistic Theory Conference. Ithaca: Cornell University. 342-359. doi:10.3765/salt.v19i0.2524.

Pintér Lilla 2016. A magyar szerkezeti fókusz kimerítő értelmezésének kísérletes vizsgálata. In Balázs József - Bojtos Anita - Paár Tamás - Tompa Zsófia Turi Gergő - Vadász Noémi (szerk.) Studia Varia - Tanulmánykötet. Budapest: Pázmány Péter Katolikus Egyetem Bölcsészet- és Társadalomtudományi Kar. 191-212.

Riester, Arndt 2008. A semantic explication of information status and the underspecification of the recipients' knowledge. In Atle Grønn (szerk.) Proceedings of Sinn und Bedeutung 12. Oslo: ILOS. 508-522.

Skopeteas, Stavros - Gisbert Fanselow 2011. Focus and the exclusion of alternatives: On the interaction of syntactic structure with pragmatic inference. Lingua 121/11 (Focus Marking Strategies and Focus Interpretation):16931706. doi:10.1016/j.lingua.2011.05.005.

Surányi Balázs 2011. A szintaktikailag jelöletlen fókusz pragmatikája. In Bartos Huba (szerk.) Általános Nyelvészeti Tanulmányok XXIII. Új irányok és eredmények a mondattani kutatásban. Budapest: Akadémiai Kiadó. 281-313.

Szabolcsi, Anna 1981. Compositionality in focus. Folia Linguistica 15/1-2:141-162. doi:10.1515/flin.1981.15.1-2.141.

Szabolcsi, Anna 1994. All quantifiers are not equal: The case of focus. Acta Linguistica Hungarica 42/3-4:171-187.

Wedgwood, Daniel 2005. Shifting the Focus: From Static Structures to the Dynamics of Interpretation. Oxford: Elsevier.

Zimmermann, Malte 2008. Contrastive focus. In Caroline Féry - Gisbert Fanselow Manfred Krifka (szerk.) The Notions of Information Structure. Working Papers of the SFB 632. (Interdisciplinary Studies on Information Structure 6) Potsdam: Universitätsverlag. 147-159.

\section{A szerzőkről}

Tóth Enikő a Debreceni Egyetem Angol-Amerikai Intézetének egyetemi adjunktusa. Főbb kutatási területei a mód és a modalitás, a szemantika és a nyelvelsajátítás, valamint a kísérletes pragmatika.

Elérhetősége: toth.eniko@arts.unideb.hu

Csatár Péter a Debreceni Egyetem Germanisztikai Intézetének egyetemi docense. Főbb kutatási területei a metafora és a figuratív nyelvhasználat pragmatikája és a nyelvészeti metaforaelméletek módszertani kérdései.

Elérhetősége: csatar.peter@arts.unideb.hu 